\title{
Between Doctrine and Practice: The UN Peacekeeping Dilemma
}

\section{Mateja Peter}

\begin{abstract}
Mandates of recent peacekeeping operations across Africa have shown substantial innovation in the thinking of the UN Security Council. Offensive use of force, use of unmanned aerial vehicles, strategic intelligence and communication, and state-building mandates in the midst of conflicts have all expanded the scope of activities beyond what the UN peacekeepers are accustomed to. The UN is entering a new era of enforcement peacekeeping. Enforcement peacekeeping manifests itself both in enforcement of political solutions through support of a government's statebuilding ambitions and its attempts to extend state authority in the midst of conflict and in enforcement of military victories through the offensive use of force. These developments further unsettle the basic principles of UN peacekeeping —consent, impartiality, and nonuse of force-resulting in a schism between the doctrine and practice. This contribution argues that such fundamental challenges, when not properly acknowledged, create a wall between operational activities and strategic considerations. They preclude a proper debate on the problematic externalities, in particular on political processes and peacebuilding. KEYWORDs: peacekeeping, peacebuilding, peace enforcement, enforcement peacekeeping, United Nations, African Union, DRC, Mali, Somalia.
\end{abstract}

... to prevent the expansion of all armed groups, neutralize these groups, and to disarm them.

- UN Organization Stabilization Mission in the Democratic Republic of the Congo (MONUSCO) list of tasks, UN Security Council Resolution S/RES/2098 (28 March 2013)

... to stabilize the key population centres, especially in the north of Mali and, in this context, to deter threats and take active steps to prevent the return of armed elements to those areas.

-UN Mission in Mali (MINUSMA) mandate, UN Security Council Resolution S/RES/2100 (25 April 2013)

In spring of 2013, the UN Security Council expanded the mandate of a long-standing peacekeeping mission in the Democratic Republic of Congo (DRC) and established a new operation in Mali. Both of these missions are operating in highly challenging environments, environments where the Security Council and the UN Department of Peacekeeping Operations would traditionally be reluctant to deploy. More important, both missions 
have unprecedentedly robust mandates, further expanding and drawing attention to the range of activities that UN peacekeepers have recently been engaging in and supporting. Authorization of an intervention brigade, references to unmanned aerial vehicles (drones) in mission mandates, invocation of explicit links between terrorism and organized crime, and support for extension of state authority in the midst of open conflicts are all changing the nature of peacekeeping. Moreover, in practice, peacekeeping operations have started to rely on new capabilities such as the use of strategic communication and, more recently, military intelligence. UN peacekeeping is increasingly bearing a resemblance to the stabilization missions in Afghanistan and Iraq. It is erasing the line between peacekeeping and peace enforcement, opening questions about future developments and repercussions. UN peacekeeping seems to be going down the path not only of enforcing military solutions through offensive action, but also of presuming and precluding particular political solutions by siding with (often contested) governments.

Recent UN peacekeeping practice is not aligned with its doctrine. This tension has not escaped informed observers ${ }^{1}$ or the UN itself. Both the member states and the UN Secretariat through the Department of Peacekeeping Operations are cognizant that they are encountering a range of new problems. Concerns about nonstate actors and nontraditional threats top the list. Consequently, the UN is engaging in major efforts to strengthen its capability-driven approach to peacekeeping with an aim to respond to the challenges of the twenty-first century. However, while these reform initiatives attempt to address many of the practical concerns arising out of increasingly robust missions (including growing budgets and troop commitments), ${ }^{2}$ these endeavors have endorsed, advocated, and been underpinned by the basic principles of UN peacekeeping as developed through the Brahimi Report and the Capstone Doctrine: consent, impartiality, and nonuse of force. ${ }^{3}$ They heavily invoke the Capstone principles in what amounts to almost a collective denial of the mismatch between the doctrine and practice.

The argument presented here proceeds in two parts. First, I demonstrate that the recent innovations in peacekeeping fundamentally challenge the Brahimi Report, the Capstone Doctrine, and their understanding of what peacekeeping is. Second, I argue that such fundamental challenges, when not properly acknowledged, create a wall between operational activities and strategic/doctrinal considerations. Thus, they preclude a proper debate on the problematic externalities of the new peacekeeping reality. In this article, I address the repercussions of expanding mandates on political processes and longer-term peacebuilding activities. I argue that the lack of acknowledgment of a doctrinal shift complicates developments and planning in host states and regions in the long run. 
This article is structured into four sections. First, I look at the reality of contemporary peacekeeping, highlighting that UN peacekeeping practice is learning from stabilization missions in Iraq and Afghanistan. Second, I outline the doctrinal mismatch and the UN responses to it. I show that these responses have not recognized the extent of a gap between the reality and the doctrine. Third, I explore implications of these changes for UN peacekeeping and international efforts. Fourth, I address repercussions for political processes and peacebuilding in the host state and region. In the conclusion, I reflect on what this new era of enforcement peacekeeping means for the UN and its role in conflict resolution and management.

\section{New Realities of UN Peacekeeping}

After a period of steady growth from the late 1990s on, the UN peacekeeping expansion seemed to have started contracting toward the end of the past decade. Three large-scale operations in Kosovo, Timor-Leste, and Liberia were slowly drawing down, planning their exits, and transitioning to peacebuilding activities. In addition, the global financial crisis of 2008 presented a sobering moment for international peacekeeping, putting substantial pressures on any and all proposals to reduce budgets and curtail tasks. Experiences with the stabilization missions in Iraq and Afghanistan contributed to this broad disillusionment over large-scale and potentially protracted international interventions. Peacekeeping was seemingly in less demand. However, this development did not last long. Not only has the Security Council authorized a deployment of 12,000 troops and police to Mali ${ }^{4}$ and 10,000 to the Central African Republic (CAR $)^{5}$ - the scale of missions we have not seen since before the financial crisis-but the types of activities that the new missions and the newly enhanced missions are mandated to perform substantially expand and change the nature of UN peacekeeping. After traditional and multidimensional peacekeeping, we are now entering a new era of enforcement peacekeeping. ${ }^{6}$

Enforcement peacekeeping manifests itself both in enforcement of political solutions through support of a government's state-building ambitions and its attempts to extend state authority in the midst of conflict and in enforcement of military victories through offensive use of force. This is connected to the fact that the targets of peacekeeping actions are nonstate actors that enjoy little international legitimacy due to their appalling human rights or war crimes records. As a result, no comprehensive peace agreements with them are sought before peacekeepers are deployed, something that is in stark contrast to both traditional and multidimensional peacekeeping. As outlined below, these missions bear resemblance to the stabilization missions in Iraq and-even more starkly-Afghanistan. Unlike UN operations, the mission in Afghanistan was Security Council-mandated but car- 
ried out by a US-led coalition of mostly Western states, with the UN footprint being light in the form of a special political mission. ${ }^{7}$ While the missions in Iraq and Afghanistan could hardly be described as successful, the UN is emulating them as it is confronting actors seemingly similar to alQaeda and the Taliban (e.g., Al-Shabaab, M23, Boko Haram, and al-Qaeda in the Islamic Maghreb). However, as the appetite for unilateral or coalition-led interventions has decreased among the Western powers, these operations are now conducted on a smaller scale in the context of UN peacekeeping, with an intention to manage and contain these conflicts. The following paragraphs provide an illustration of some of these new activities and hint that a seismic change is under way.

One of the more striking innovations in UN peacekeeping is the introduction of targeted combat operations and the switch from defensive to offensive peacekeeping. Most noticeably, this has been the case in the DRC, where the Security Council authorized the inclusion of a "force intervention brigade" within an existing UN Organization Stabilization Mission in the Democratic Republic of the Congo (MONUSCO) mission structure. This is the "first-ever 'offensive' combat force" in UN peacekeeping. ${ }^{8}$ The brigade was set up with an intention to "neutralize and disarm"- a euphemism widely used by the military when engaging in offensive operationsthe Tutsi March 23 (M23) militia in the eastern parts of the DRC. This group had previously put increasing pressure on both the Congolese forces and UN peacekeepers and, in November 2012, even managed to seize the regional center of Goma. At the same time, while the expansion of the mission was prompted by recent activities of M23, the Security Council resolution is framed considerably more broadly. It mandates UN peacekeepers to assist Congolese forces in fighting all armed groups, listing the Democratic Forces for the Liberation of Rwanda (FDLR) and the Lord's Resistance Army (LRA) as two other examples. This is the first time in the history of UN peacekeeping that the Security Council has created a list of enemies that UN peacekeepers are supposed to neutralize. The language of the resolution and the types of activities that UN peacekeepers are mandated to perform imply that the UN is engaged in a battle in coalition with the Congolese government, the same government that the UN and other international actors have repeatedly criticized for condoning serious abuses by its military against civilians. ${ }^{9}$

While the Congolese experience has not been entirely replicated in other missions (yet), it does conform to a wider trend in UN peacekeeping. MINUSMA, the UN operation in Mali, does not have a mandate that is as explicitly offensive as the mission in the DRC. While some Security Council member states were flirting with such an idea, in the end the mandate does not directly authorize UN offensive actions. This is partly because of the Secretary-General's concerns about the inability of UN troops to engage 
in desert combat, and partly due to reluctance of emerging powers to authorize such a mandate under UN control. ${ }^{10}$ However, when the UN mission was established, it assimilated the extant Economic Community of West African States (ECOWAS) mission AFISMA. And AFISMA had previously been authorized by the Security Council to support the government of Mali, an ECOWAS member nation, in its fight against Islamist rebels in the northern Mali conflict. ${ }^{11}$ Moreover, the resolution establishing MINUSMA also authorized French troops conducting Operation Serval to use all necessary means to intervene within the limits of their capacities and areas of deployment in support of elements of MINUSMA when under imminent and serious threat and on request of the Secretary-General. Operation Serval, which has been in Mali since the end of 2012, was deployed following an official request by the Malian interim government. Its aim is to oust Islamic militants in northern Mali. By associating MINUSMA with Operation Serval, the Security Council in essence authorized an intervention brigade, just not under the UN command.

Similarly, in Somalia, the Security Council established a political mission with a mandate to support the government and African Union Mission in Somalia (AMISOM) peacekeepers. ${ }^{12}$ These are in essence fighting a war against Al-Shabaab, which means that the UN is associated with those activities. Richard Gowan further writes that an African Union regional intervention force, currently under development, "could potentially conduct aggressive military operations not only in parts of the DRC patrolled by UN troops, but also in South Sudan and the Central African Republic."13 The deployment of offensive combat troops is thus far-reaching, and even when the UN is not deploying these forces itself, it is supporting regional organizations and states in ways that their actions are not clearly detached. ${ }^{14}$

At the same time, the UN not only engages in military action against particular targets, in coalition with the host state, but also assists these states in their state-building attempts. In the case of Somalia, the UN Assistance Mission in Somalia (UNSOM) is supporting the government in the development of a federal system. ${ }^{15}$ Both MINUSMA in Mali and MONUSCO in the DRC have extension of state authority as part of their mandates. Support for particular state structures is occurring without a comprehensive peace agreement in place.

In parallel, UN peace operations have seen an increasing deployment of regional actors that are part of the conflict dynamics. For the entire peacekeeping history, there has been a strong reluctance to deploy peacekeepers to areas where they could be seen as acting as instruments of their governments' policies. ${ }^{16}$ When regional actors have been deployed as part of a UN mission, for example, Australia in Timor-Leste (UN Transitional Administration in East Timor, UNTAET) or Nigeria in Sierra Leone (UN Assistance Mission in Sierra Leone, UNAMSIL), this has been with the 
consent of all main parties to the conflict and after a comprehensive peace agreement was in place. As discussed below, the rationale for excluding regional actors with interest in the conflict outcome not only has to do with obtaining consent, but also with making sure that UN peacekeeping is not used as a political tool. The policy is intended to protect the credibility of operations as well as to protect peacekeepers themselves from attacks.

In the African context, where sovereign borders are a result of a colonial logic, such cross-border interests are even more apparent. While UN peace operations as a rule have a single-state mandate, the conflicts in Mali, Somalia, the DRC, the CAR, Sudan, and South Sudan, to mention only some, are all regional conflicts. Their neighboring states are part of the conflict dynamics. However, prohibition against deployment to areas where states have interests is now changing. ${ }^{17} \mathrm{UN}$ operations increasingly rely on regional contributions, not least because only highly interested states are willing to risk the lives of their troops in increasingly robust operations. That is, regional states are interested in conflicts that affect their security and political interests, therefore they are willing to contribute to high-risk situations.

A prime example of this development is MINUSMA, which by incorporating AFISMA became ostensibly a mission composed of regional troops. The largest troop contributors to the Mali mission are Chad, Burkina Faso, Niger, Togo, and Senegal, all regional states. ${ }^{18}$ Regional troops are also the ones primarily deployed to the most volatile northern parts of Mali. In the DRC, the primary contributors to the intervention brigade are South Africa, Tanzania, and Malawi, while the rest of the MONUSCO mission is composed mainly of South Asian troops. Similarly, the UN-supported African Union mission in Somalia consists mostly of regional troops from Kenya, Uganda, Burundi, Ethiopia, and Djibouti. Such a composition has already shown to be problematic, with Kenyan peacekeepers profiteering in the local charcoal trade and Ethiopian troops, which have a long history of invasions of Somalia, being extremely unpopular among the local population. ${ }^{19}$ Likewise, the presence of Chadian soldiers in the African-led International Support Mission to the Central African Republic (MISCA) has been highly polarizing due to Chad's perceived backing of the Muslim rebel group Séléka, which overthrew the CAR government. In one incident, peacekeepers fired on a crowd protesting the presence of the Chadian troops. As a result, to diffuse the tensions, these troops were redeployed outside of the mostly Christian capital. ${ }^{20}$ The plan of the UN Multidimensional Integrated Stabilization Mission in the Central African Republic (MINUSCA) is to incorporate these troops akin to MINUSMA in Mali. ${ }^{21}$

As these examples aptly demonstrate, the Security Council is increasingly becoming more willing to deploy peacekeepers where there is no peace to keep. The short-lived UN Supervision Mission in Syria, which had to terminate its activities after only four months, is a good recent example 
of the Security Council deploying operations to a war zone. The mission was scrapped due to the accumulation of obstacles to its mandate's implementation that had "rendered operational activities unworkable." 22 However, its mere deployment highlights that the Security Council is willing to use peacekeepers in increasingly risk-prone areas. Moreover, not only are such deployments into conflict areas intended to monitor cease-fires and protect civilians and humanitarian aid, but the peacekeeping tasks in the midst of conflict zones are expanding. Peacekeepers are now often protecting states. In Somalia, the UN is engaging in disarmament, demobilization, and reintegration (DDR), an activity normally conducted after the peace agreement has been signed. ${ }^{23}$ The peacekeeping mission in the CAR is entering into the conflict with the same mandate. How one is supposed to effectively demobilize and reintegrate former combatants, when their fellow fighters have not laid down their arms, has not been sufficiently addressed. But experiences in Afghanistan demonstrate that not properly acknowledging political realities of an ongoing conflict largely undermines the DDR process. ${ }^{24}$ As mentioned above, the UN political mission in Somalia is also asked to support "the development of a federal system" 25 — while the government and AMISOM are fighting a war against Al-Shabaab, and the future of the country is highly uncertain.

The reality that UN peacekeepers are increasingly involved in enforcement of political and military solutions is also seen in the types of capabilities that these missions are relying on. The UN has advocated the use of surveillance drones in the eastern DRC, on the border between Côte d'Ivoire and Liberia, in South Sudan, and in Mali. ${ }^{26}$ In Mali, peacekeepers have openly been relying on strategic intelligence, an activity causing such unease for decades among the Global South nations that in 1960 then Secretary-General Dag Hammarskjold categorically rejected a possibility for a UN intelligence agency on the grounds that the organization "must have clean hands." 27 The Brahimi Report advocated for the incorporation of field intelligence in peace operations so that they could better respond to complex situations, ${ }^{28}$ but these recommendations were not favorably viewed by the member states. While the UN has always relied on some tactical intelligence and information from other sources' intelligence activities, an outright and open incorporation of strategic intelligence into UN peacekeeping missions is new and setting precedents. ${ }^{29}$ In a similar development, in Somalia the UN is engaged in strategic communication campaigning and has hired a consultancy firm that, according to its statements, "runs a fully integrated campaign to counter the radicalising effect of Al-Shabaab and engage Somalis in building a positive future for their country." 30 Drones, intelligence, and strategic communication all evoke ideas of stabilization missions. The major difference is that the UN peacekeeping activities as a rule are conducted on request of governments in target states. 


\section{The Delusion of a Doctrine}

UN peacekeeping is underpinned by three key principles: consent, impartiality, and the nonuse of force. In this section, I briefly explore their meaning as defined by the Capstone Doctrine and demonstrate that recent practice is not in line with these principles. I further examine how the UN has been responding to this mismatch.

\section{Consent}

UN peacekeeping operations are supposed to be deployed with the consent of the main parties to the conflict. This distinguishes them from enforcement operations. Consent requires a commitment by the parties to a political process. As the Capstone Doctrine argues, "In the absence of such consent, a United Nations peacekeeping operation risks becoming a party to the conflict; and being drawn towards enforcement action, and away from its intrinsic role of keeping the peace." ${ }^{11}$ This is not just for normative reasons, but also for purely practical ones. Consent is sought to make the work and tasks of UN peacekeepers more achievable. It is usually obtained through a peace agreement among main parties to the conflict. While peacekeepers are deployed to volatile situations, they are not intended to conduct their activities in the midst of open conflicts.

The examples above show that consent is missing in contemporary operations, mainly because comprehensive peace agreements are lacking. While the problem of spoilers has always existed in peacekeeping, the new operations take an additional step away from seeking consent of the main parties. ${ }^{32}$ Missions such as the ones in the DRC, Mali, and Somalia are deployed to empower the state's government and help it defeat one of the parties to the conflict. "Expansion of state authority" is now often part of a mission's mandate. Importantly, the targeted parties possess enough political and military power that governments are unable to defeat them by themselves. These groups therefore cannot be thought of as anything else but a main party to the conflict. Such peacekeeping operations disregard the practical considerations for why UN peacekeepers are not supposed to conduct enforcement operations. However, their deployment happens not just for security reasons, but to a large extent also for a moral one. The latter often tips the scale toward the Security Council's willingness to deploy. AlShabaab in Somalia, al-Qaeda-affiliated groups in northern Mali, and to a large extent also the LRA, the FDLR, and M23 militias in the eastern DRC are not considered legitimate participants to the conflict; therefore, their consent is not sought. These groups often find themselves on terrorist lists of Northern states, making members of the Security Council as a whole even less willing to allow them any legitimate claims. But the lack of legitimacy among interveners does not mean a lack of legitimacy among the local population or a lack of political agency. 


\section{Impartiality}

According to the Capstone Doctrine, UN peacekeeping missions must implement their mandates without favor or prejudice to any party. Furthermore, impartiality is seen as "crucial to maintaining the consent and cooperation of the main parties, but should not be confused with neutrality or inactivity." ${ }^{33}$ It is clear that the cornerstone of impartiality is actually consent to peacekeeping activities; impartiality is intended to ensure the continued cooperation of all key political players so that the operation can successfully implement its mandate. In addition, the Brahimi Report clearly argues that "the United Nations does not wage war," and continues that when such action is required it is entrusted to coalitions of willing states with the authorization of the Security Council. ${ }^{34}$

The new peacekeeping operations are far from being impartial to main parties to the conflict. In this context, the lack of consent makes it impossible for these operations to be impartial even in principle- the missions are mandated to be partial. We have seen this not only in enforcement missions like the ones in the DRC and Mali, but also in South Sudan and more recently in Somalia, where the UN is building new states in collaboration with the government and against the interests of other political players. It is thus producing a specific partial reality. But not only are UN peacekeeping operations mandated "to side with the government" against interests of other parties; these missions are also staffed by personnel from parties that have vested interests. As discussed in the previous section, many new missions are composed of troops sent by regional states that are part of the conflict dynamics. The Great Lakes region, the Horn of Africa, and the Sahel have long been recognized as regional conflicts (e.g., the European Union now has regional strategies on all three). However, when composing missions to these areas, the consideration of impartiality is trumped by the need to acquire a sufficient number of personnel. It thus is not entirely clear whether troops participating in these missions are deployed to uphold the peacekeeping mandate or to protect immediate interests of the states contributing them. Their impartiality is suspect.

\section{Nonuse of Force}

The principle of nonuse of force except in self-defense is one of the cornerstones of peacekeeping and dates back to the first deployments of armed UN peacekeepers. ${ }^{35}$ Despite this principled prohibition, it is widely understood that peacekeepers may use force at the tactical level, with the authorization of the Security Council and if acting in self-defense or defense of the mandate. A move toward more robust mandates in the post-Cold War era led to the Security Council's willingness to authorize UN peacekeepers to use all necessary means to "deter forceful attempts to disrupt the political process, protect civilians under imminent threat of physical attack, and/or assist the 
national authorities in maintaining law and order."36 Beginning in the 1990s, there has been a continuously increasing tolerance for the use of force in peacekeeping.

However, the new mandates present a further qualitative shift, moving from defensive toward offensive use of force. The UN not only is using force to protect the peace agreement, civilians, or itself-all established reasons for the use of force-but also to protect and assist the host state and its government. In this respect, the intervention brigade in the DRC is particularly telling. While past operations could use force to protect their mandates, now the use of force is an important part of the mandate itself. Not only do the objectives of the mission need to be protected through the use of force, but they cannot be achieved without it. As with the abrogation of consent and impartiality, such use of force is connected to the lack of legitimacy of the groups being targeted. These groups operate outside the traditional international system of collective security, allowing for exceptional measures. ${ }^{37}$ However, as argued above, that does not deprive these groups of political agency or legitimacy among the local population. Of the three key principles, the Security Council is the least comfortable abrogating the nonuse of force. The Security Council resolution establishing an intervention brigade as part of MONUSCO even clearly states that such brigade is created "on an exceptional basis and without creating a precedent or any prejudice to the agreed principles of peacekeeping." 38 Based on experience from other theaters, it is clear that the Security Council is more comfortable in relying on regional groupings and interested parties (e.g., France in Mali, AMISOM in Somalia) to perform these tasks, even if the UN mission is directly supporting them.

\section{Responses}

These changes in the practice of peacekeeping have been met with some reluctance, particularly by states from the Global South. When discussing establishment of an intervention brigade as part of MONUSCO in the DRC, the representative of a nonpermanent Security Council member, Guatemala, worried that the mission was bordering on a peace enforcement one. ${ }^{39}$ The ambassador reasoned that the UN should always be seen as an "honest broker" and that, while his country understood the logic behind the proposed deployment, it would have preferred the brigade to be a self-standing unit with specific duties distinguishable from those of MONUSCO's other work. ${ }^{40}$ This communicated the unease about long-term implications of a new type of activity for broader missions. In the same debate, the representative from Argentina supported this sentiment. He claimed that, although the text clearly stated that the brigade would not set a precedent, the idea of "enforcing peace rather than keeping it" required deep reflection, not just a week of negotiations. The Argentinian representative also argued for a better consultation 
process with troop contributors, so that they could be better apprised of the new activities. ${ }^{41} \mathrm{He}$ hinted at the potentially problematic consequences of separating political considerations at the Security Council level from practical realities on the ground. Similarly for the MINUSMA mission in Mali, Argentina, Guatemala, Pakistan, and Russia pushed for a clear mention in the preamble of the basic principles of peacekeeping-consent of the parties, impartiality, and nonuse of force. ${ }^{42} \mathrm{~A}$ number of member states, particularly the emerging powers, are showing resistance to the direction that peacekeeping is moving into.

While the reality on the ground is changing and the Security Council is becoming more willing to authorize robust missions, the official UN responses to these challenges have not acknowledged the extent of the mismatch between doctrine and practice. The resolutions establishing these missions characterize their activities as exceptions, despite practical evidence to the contrary. Moreover, the last peacekeeping review process was silent on the extent of these challenges. The New Horizon process, as the review was called, was designed to "assess the major policy and strategy dilemmas facing UN Peacekeeping today and over the coming years" and "reinvigorate the ongoing dialogue with stakeholders on possible solutions to better calibrate UN Peacekeeping to meet current and future requirements." ${ }^{43}$ However, while the process was supposed to adjust and adapt UN peacekeeping to meet new and emerging challenges, it only reinforced previous review documents. The Secretary-General's Report to the Special Committee on Peacekeeping Operations identified four reform priorities- policy development, capability development, global field support strategy, and planning and oversight—all very practically, capability oriented. ${ }^{44}$

The nonpaper that kicked off this peacekeeping review process addressed the question of robustness in UN missions, but phrased it narrowly: "The concept of 'robustness' in UN peacekeeping is a political and operational strategy to signal the intention of a UN mission to implement its mandate and to deter threats to an existing peace process in the face of resistance from spoilers." 45 Robustness is intended to describe defensive aspects of the use of force, not offensive ones. Moreover, the nonpaper also limited the space for possible discussions about doctrinal implications in further debates by providing that robustness "is rooted in the guiding principles that are the foundations of UN peacekeeping: nonuse of force except in self-defence and defence of the mandate, consent of the main parties and impartiality in implementation." 46 There was no discussion of any possible doctrinal changes or challenges.

At the June 2014 open debate of the Security Council on "new trends in UN peacekeeping operations," Secretary-General Ban Ki-moon announced that he had asked the Secretariat to initiate work on a review of UN peacekeeping. While his speech focused on new threats and needed capabilities 
and steered away from discussing the doctrine, it did offer a possibility for such a debate by asking what the limits of UN peacekeeping are. ${ }^{47}$ The ongoing review process consists of two parallel but interrelated efforts on the part of the High-Level Independent Panel on UN Peace Operations, chaired by Nobel Laureate José Ramos-Horta, and the UN Secretariat. This process presents another opportunity to openly address where the UN peacekeeping practice does not fit its doctrine anymore. A continued denial of the mismatch has potentially negative implications for what these missions can achieve and how places where they intervene can be transformed.

\section{Implications for UN Peacekeeping and Humanitarian Efforts}

Abrogation of peacekeeping principles is bound to carry unintended consequences. While the full extent of these is difficult to foresee, considering the stakes involved for both the hosting states and the future of UN peacekeeping, this kind of an assessment is needed as part of strategic considerations. In this section, I examine a series of repercussions of expanding mandates for execution of peacekeeping operations and for other international engagements, highlighting that both security and implementation of mandates could become complicated.

It is not unreasonable to expect that peacekeepers taking sides in a conflict will result in increased resistance from disenfranchised groups. We have seen this in the CAR, where deployment of Chadian peacekeepers resulted in protests, and even more clearly in the DRC, where on establishment of a UN intervention brigade the president of the rebel group M23 vowed, "If UN forces come and attack us they will find us here and if they [are] against us, we will fight." 48 Although there was a spike in the number of fatalities caused by malicious acts in 2013 and early 2014, the time line is too short for the data to conclusively confirm an increased risk associated with more robust mandates. However, Alex J. Bellamy notes that in the past "mandates have not been interpreted as requiring the adoption of greater risks by peacekeepers." 49 With an increasing pressure to move the strategy from defensive to offensive thinking, it is reasonable to expect that fatalities will increase.

Offensive mandates also expose to harm other parts of the peacekeeping mission. UN peacekeeping has been continually moving toward greater complexity. Individual mission mandates now cover a broad range of issues and involve political, security, humanitarian, refugee, gender, and other components. Any offensive parts of the operation thus inevitably form only a small part of the overall mission. For example, the intervention brigade in the DRC consists of roughly 3,000 troops, out of around 22,000 total MONUSCO staff. However, activities of offensive components could have negative spillover effects on other parts, in particular, as these are less prepared for 
combat and thus more vulnerable to attacks. Displaying a UN mission symbol, which historically provided peacekeepers with an invisible layer of protection, could come to mean exactly the opposite. It could be an invitation for retaliation. It is for this reason that some member states, as discussed above, wanted offensive components of the DRC mission to be separated from the broader peacekeeping operation.

However, separating combat elements from the rest of the mission or assigning such tasks to non-UN actors that are tightly knit with the peacekeeping operation (e.g., France in Mali, AMISOM in Somalia) addresses only the legal aspects of the problem. It does not resolve how these operations can end up being perceived by potential retaliators. The UN itself has been moving toward an integrated model of operation on the ground. Such an approach was introduced to ensure coherence of UN action across security, development, and governance in conflict and postconflict zones. ${ }^{50}$ Although individual components remain functionally separate, their operation in the field takes place within integrated teams. ${ }^{51}$ Integrated missions make it more difficult to distinguish one part of the operation from the other, thus potentially implicating all components of UN activity into problematic activities of one of its parts.

The humanitarian community has been raising concerns over an integrated approach to UN presence. Many aid actors are opposed to increasing integration on principle, as it blurs the distinction between military, political, and humanitarian action and subordinates humanitarian priorities to political agendas. It also changes the nature of aid activities by pushing humanitarian actors into compounds and, thus, further away from aid recipients. ${ }^{52}$ Studies indicate that closer cooperation among international actors can have both positive and negative effects. ${ }^{53}$ However, UN political support for highly contested governments and an increasing robustness of operation are likely to further politicize international peacekeeping and exacerbate negative effects on the aid community. Aid actors' ability to act independently and impartially could be severely challenged.

Finally, the increasing robustness of missions and their state-building mandates in the midst of conflicts are likely to complicate their success and extraction. Consent of the main parties has been established as a necessary condition for a mission's success. ${ }^{54}$ It is difficult to foresee how involvement of UN peacekeepers in combat could completely alter political realities in host states. While a particular armed group might be defeated, in conflicts that have been lasting for decades-such as the ones in the Great Lakes region or the Sahel — other groups with similar agendas and similar motivations are likely to emerge. This could involve combat forces in protracted engagements that are difficult to end. Lessons from Afghanistan, Iraq, and Syria apply here if on a smaller scale. However, what is more likely is that the Security Council will terminate combative elements of those missions that are not considered of 
high interest to the Security Council members, before a proper political settlement is reached. This would inevitably leave the rest of the mission with more difficulties in completing its mandate. Similarly, it is also highly problematic that the Security Council is assigning state-building tasks to missions operating in the midst of conflicts. How these tasks are supposed to be successfully completed, so operations do not remain trapped, has not been sufficiently considered. Without a peace to keep, there is no state to build.

\section{Implications for Conflict Dynamics and Peacebuilding}

When UN peacekeepers side with one side in a conflict, whether by helping it extend state authority or defeat enemy combatants, this substantially affects conflict and political dynamics at a particular time. It confers legitimacy on one set of actors while delegitimizing the claims of others. It also empowers specific actors against others in ways that might be unsustainable in the long run. Here, I provide a broader assessment of likely implications of expanding mandates for host states and regions, focusing on political processes, peacebuilding, and regional conflict dynamics.

Conflict parties against which the government and now UN action is directed are key players in a conflict. Why else would a government need international assistance in countering them and their influence? Regardless of their international legitimacy, these armed groups or their political reincarnations will need to be included in peace settlements if these are to become sustainable. Such was the practice in the past. The UN undoubtedly is cognizant of this. However, trying to be an impartial broker in a peace process, while at the same time attempting to neutralize and disarm one of the parties, creates internal contradictions. Although it is not unusual for negotiating parties to be suspicious of the impartiality and benevolent intents of outside brokers, when a broker openly takes sides in a conflict such a claim acquires more credibility.

The Congolese developments are already exposing a number of difficulties in trying to pursue negotiations simultaneously with enforcement mandates. In December 2012 and under heavy international pressure, M23 agreed to pull out from Goma in exchange for the start of negotiations with the Kinshasa government. Less than four months later, the Security Council authorized a UN intervention brigade. At the time, the UN envoy for Africa's Great Lakes region, Mary Robinson, reiterated her support for the stalled Kampala talks between the DRC government and the M23 group, and she urged Congolese president Joseph Kabila "to remain committed to this process with a view to expediting it as soon as possible." ${ }^{55}$ In response to the UN's decision to deploy an intervention brigade, M23 representatives walked out of negotiations.

When they returned to the negotiating table a couple of months later, the talks were marred with problems and accusations. However, while the moti- 
vations and commitment of M23 to a diplomatic solution are highly suspect, the military and political backing of the international community also empowered the DRC government to assume a maximalist take-it-or-leave-it position in the negotiations. DRC government spokesperson Lambert Mende Omalanga told IRIN by phone, "It depends on whether M23 is ready to accept ... what has been decided in Addis Ababa and [in the] UN for them to disarm. If they accept, we are ready to finalize the Kampala process." 56 With support from UN peacekeepers, the DRC government was more likely to defeat M23 militarily, thus improving its negotiating position. The M23 rebels were defeated in November 2013, leading to the completion of the Kampala process a month later. While both sides agreed to a number of commitments, their implementation is experiencing serious setbacks.

The UN's support for the central government politically or militarily empowers one side and can result in a peace settlement that fails to reflect the political reality on the ground. This complicates longer-term peacebuilding and reconciliation processes. Armed groups against which the new UN peacekeeping mandates are directed often hold little legitimacy in the eyes of the outside world. They do, however, either enjoy popular support of wide segments of the local population, such as Al-Shabaab in Somalia, or more commonly, raise real concerns and grievances that the local population has against the government. More than half a year after M23's military defeat, the former M23 spokesperson highlighted a number of concerns that the group had been raising, but that had not been addressed by the government: "the need to return assets of the Congolese people that were confiscated, stop discrimination against Congolese in eastern part of the country and return of refugees who are scattered in the neighbouring countries." 57 Despite the undoubtedly political motivations of the source, these are serious and legitimate concerns that are crucial to any peacebuilding and reconciliation effort. However, with the defeat of the party airing such grievances, these do not need to be comprehensively addressed in a peace agreement. This makes it more likely that a reincarnation of the defeated group will emerge in one form or another, making peace unsustainable.

Finally, there is a need for a broader consideration of how enforcement peacekeeping could impact regional dynamics. The conflicts in Mali, Somalia, the DRC, the CAR, Sudan, and South Sudan, among others, are all regional conflicts. At the same time, UN peacekeeping operations, as a rule, have a single-state focus. Militarily defeating an armed group in a particular state, such as Al-Shabaab in Somalia or al-Qaeda-affiliated groups in northern Mali, could move some of their operations to neighboring states. We have seen this in the past in the Middle East and in Africa. In their introduction to a special journal issue on how the intervention in Libya influenced the conflict dynamics in the Sahel, Morten Bøås and Mats Utas argue that, while in the Mali conflict "recapturing large parts of north- 
ern Mali from the Islamists may have been a relatively easy military operation, controlling this vast territory will be much more difficult and timeconsuming. ${ }^{" 58}$ Spillover to neighboring states can be expected when underlying conflicts remain unresolved.

\section{Conclusions}

The UN is moving toward a new era of enforcement peacekeeping. This has manifested itself both in enforcement of political solutions through support of governments' state-building ambitions in the midst of conflicts and in enforcement of military victories through offensive use of force. These changes demonstrably challenge all three key peacekeeping principles: consent, impartiality, and nonuse of force. Such a shift in UN peacekeeping opens the door to a number of unintended, but problematic, consequences. In contemporary peacekeeping, the targets of peacekeeping actions tend to be nonstate actors that enjoy little international legitimacy. As a result, no comprehensive peace agreements with them are sought before the international community takes sides in a conflict. UN peacekeeping is bearing a startling resemblance to the stabilization missions in Afghanistan and Iraq, whose mixed short-term results and unaccomplished longer-term objectives should hold lessons for UN peacekeeping.

Recent developments raise dilemmas that are similar to those of mid1990s peacekeeping. Two decades ago the international community was engaging in robust operations (Somalia), establishing safe havens (the former Yugoslavia, Rwanda), and creating protracted transitional administrations merging peacekeeping with state building (Cambodia, Timor-Leste, and Kosovo). UN peacekeeping suffered many setbacks during that era, leading some to speculate on its demise. In the end, these developments led to reaffirmation of the founding principles of UN peacekeeping through the Brahimi Report. Importantly for the argument here, developments in the 1990s were occurring ad hoc and in parallel to the peacekeeping doctrine. This resulted in a number of problematic consequences that were not addressed in strategic preparations. Similar developments are occurring with more recent peacekeeping expansions and risk analogous failures.

The future of peacekeeping is at stake. There is a need to acknowledge the trap brought by the merger of peacekeeping and peace enforcement and tasking peacekeepers to assist governments to build states in the midst of conflict. It is unlikely that the nature of challenges emanating from contemporary conflicts will change substantially in the near future. It thus is not enough to reaffirm the doctrine through another strategic review and then continue to ignore it in practice. In trying to resolve the tension between doctrine and practice, the UN and member states are faced with two options. They can align the peacekeeping practice more closely with the doctrine, reaffirming the UN's role in defensive and impartial tasks in 
the midst of conflict (e.g., protection of civilians) and refocus on postconflict processes and mediation. Or, they can embrace the new practices and provide for a new strategic or doctrinal underpinning. A series of exceptions constitutes a new norm. While a new doctrine would fundamentally challenge the nature of UN peacekeeping, it would at least provide for an open reappraisal of longer-term consequences of new peacekeeping practices. Sticking with the current inconsistency merely tarnishes the reputation of UN peacekeeping and undermines future deployments. (⿻

\section{Notes}

Mateja Peter is senior research fellow at the Norwegian Institute of International Affairs. Her research centers on global governance, peace operations, international organizations, and studies of the Balkans and sub-Saharan Africa.

The author thanks Morten Bøås, Cedric de Coning, Ingvild Magnæs Gjelsvik, John Karlsrud, Karli Osland, Randi Solhjell, and the three anonymous reviewers for their comments.

1. Challenges Forum, "The Death of Doctrine? Are 'Fit-for-Purpose' Peace Operations the Way Forward?" Policy Brief 2013:2 (Stockholm: Challenges Forum, 2013); Richard Gowan, "The Changing Face of Peace Operations: New Mandates and Risks for Peacekeeping and Political Missions," in Center on International Cooperation, Annual Review of Global Peace Operations 2013 (Boulder: Lynne Rienner, 2013).

2. Alex J. Bellamy and Paul D. Williams, eds., Providing Peacekeepers: The Politics, Challenges and Future of United Nations Peacekeeping Contributions (Oxford: Oxford University Press, 2013).

3. United Nations, "Report of the Panel on United Nations Peace Operations" (hereafter Brahimi Report), UN Doc. A/55/305-S/2000/809 (August 2000); United Nations, "United Nations Peacekeeping: Principles and Guidelines" (hereafter Capstone Doctrine), (UN Department of Peacekeeping Operations, 18 January 2008), www.unrol.org/files/Capstone_Doctrine_ENG.pdf, pp. 31-35.

4. UN Security Council, Res. S/RES/2100 (25 April 2013).

5. UN Security Council, Res. S/RES/2149 (10 April 2014).

6. The UN distinguishes between two generations of peacekeeping: traditional and multidimensional. Traditional peacekeeping focuses on monitoring cease-fires; in multidimensional operations, peacekeepers support the implementation of a comprehensive peace settlement. Scholars have pointed to a possible third generation focusing on employment of military means to implement a humanitarian mandate. See Connie Peck, The United Nations as a Dispute Settlement System: Improving Mechanisms for the Prevention and Resolution of Conflict (The Hague: Kluwer Law International, 1996); Oliver Ramsbotham, Hugh Miall, and Tom Woodhouse, Contemporary Conflict Resolution (Cambridge: Polity, 2011). Others have contended that the UN has developed another generation of peacekeeping-international administrations. See Christine Gray, International Law and the Use of Force: Foundations of Public International Law (Oxford: Oxford University Press, 2000).

7. For more, see Blanca Antonini, ed., Security Council Resolutions Under Chapter VII: Design, Implementation and Accountability—The Cases of Afghanistan, Côte d'Ivoire, Kosovo and Sierra Leone (Madrid: FRIDE, 2009).

8. UN News, “'Intervention Brigade' Authorized as Security Council Grants Mandate Renewal for United Nations Mission in Democratic Republic of Congo," 
SC/10964, press release (28 March 2013); UN Security Council, Res. S/RES/2098 (28 March 2013).

9 For example, UN Security Council Meeting Record S/PV.6400 (14 October 2010); Human Rights Watch, "World Report 2012: Democratic Republic of Congo, January" (New York: Human Rights Watch, 2012). For more on the recent developments in the DRC and how they are connected to the expansion of MONUSCO mandates, see J. Arthur Boutellis, "From Crisis to Reform: Peacekeeping Strategies for the Protection of Civilians in the Democratic Republic of the Congo," Stability: International Journal of Security and Development 2, no. 3 (2013): 1-11; Naomi Kok, "From the International Conference on the Great Lakes Region-led Negotiation to the Intervention Brigade: Dealing with the Latest Crisis in the Democratic Republic of Congo," African Security Review 22, no. 3 (2013): 175-180; Sandra Adong Oder, "Understanding the Complexities of the Democratic Republic of Congo at the Turn of the Decade," African Security Review 20, no. 2 (2011): 51-55; Theodore Trefon, "Uncertainty and Powerlessness in Congo 2012," Review of African Political Economy 40, no. 135 (2013): 141-151.

10. See, for example, Aljazeera, "Ban Proposes Mali Peacekeeping Force," 27 March 2013.

11. UN Security Council, Res. S/RES/2085 (20 December 2012).

12. UN Security Council, Res. S/RES/2102 (2 May 2013).

13. Gowan, "The Changing Face of Peace Operations," p. 16.

14. In the past, the UN has also deployed a UN-African Union hybrid mission in Darfur. See Thierry Tardy, "Hybrid Peace Operations: Rationale and Challenges," Global Governance 20, no. 1 (2014): 95-118.

15. UN Security Council, Res. S/RES/2102.

16. Marrack Goulding, "The Evolution of United Nations Peacekeeping," International Affairs 69, no. 3 (1993): 451-464, at 454.

17. See, for example, Jonah Victor, "African Peacekeeping in Africa: Warlord Politics, Defense Economics, and State Legitimacy," Journal of Peace Research 47, no. 2 (2010): 217-229.

18. "UN Mission's Contributions by Country," February 2014, www.un.org/en /peacekeeping/contributors/2014/feb14_5.pdf.

19. For recent controversies related to the AMISOM mission, see The Economist, "Somalia's Civil War: Pushing It Across the Borders," 8 February 2014. For background on Ethiopian involvement in Somalia, see Ismail I. Ahmed, "The Heritage of War and State Collapse in Somalia and Somaliland: Local-level Effects, External Interventions and Reconstruction," Third World Quarterly 20, no. 1 (1999): 113-127; John Prendergast and Colin Thomas-Fensen, "Blowing the Horn," Foreign Affairs 86, no. 2 (2007).

20. Aljazeera, "Chad Troops in CAR Accused of Pro-Seleka Bias," 26 December 2013; Celeste Hicks, "Chad: Déby's Misstep in the Central African Republic," Think Africa Press, 27 January 2014.

21. UN Security Council, Res. S/RES/2149. For more on the role of regional players in peacekeeping, see Gray, International Law and the Use of Force, pp. 370-425; Judith Vorrath, "When the Neigbors Keep a Foot in the Door: Regional Interventions and Peacekeeping Missions in the Democratic Republic of Congo and Somalia," in Thierry Tardy and Marco Wyss, eds., Peacekeeping in Africa: The Evolving Security Architecture (London: Routledge, 2014).

22. Report of the Secretary-General on the implementation of UN Security Council Res. S/2012/523 (6 July 2012).

23. United Nations, Integrated Disarmament, Demobilization and Reintegration Standards (2006), http://pksoi.army.mil/doctrine_concepts/documents/UN\%20 Guidelines/IDDRS.pdf. 
24. Antonio Giustozzi, "Bureaucratic Facade and Political Realities of Disarmament and Demobilisation in Afghanistan," Conflict, Security, and Development 8, no. 2 (2008): 169-192.

25. UN Security Council, Res. S/RES/2102.

26. John Karlsrud and Frederik Rosen, "In the Eye of the Beholder? The UN and the Use of Drones to Protect Civilians," Stability: International Journal of Security and Development 2, no. 2 (2013): 1-10.

27. Colum Lynch, "Dutch Double Down in Mali," Foreign Policy, 30 November 2013.

28. United Nations, Brahimi Report, par. 51.

29. For more on the UN's history with intelligence, see A. Walter Dorn, "The Cloak and the Blue Beret: Limitations on Intelligence in UN Peacekeeping," International Journal of Intelligence and Counterintelligence 12, no. 4 (1999): 414-447; A. Walter Dorn, Keeping Watch: Monitoring, Technology and Innovation in UN Peace Operations (Tokyo: United Nations University Press, 2011).

30. Albany Associates, "Somalia: AU/UN Information Support," www.albany associates.com/projects/somalia.

31. United Nations, Capstone Doctrine, p. 32.

32. See, for example, Kelly M. Greenhill and Solomon Major, "The Perils of Profiling: Civil War Spoilers and the Collapse of Intrastate Peace Accords," International Security 31, no. 3 (2007): 7-40; Stephen John Stedman, "Spoiler Problems in Peace Processes," International Security 22, no. 2 (1997): 5-53.

33. For more, see David Malone and Ramesh Thakur, "UN Peacekeeping: Lessons Learned?" Global Governance 7, no. 1 (2001): 11-17.

34. United Nations, Brahimi Report, par. 53.

35. For more on the use of force in UN peacekeeping, see Trevor Findlay, The Use of Force in UN Peace Operations (Solna: Stockholm International Peace Research Institute, 2002).

36. United Nations, Capstone Doctrine, p. 34.

37. Mateja Peter, "The Politics of Self-defence: Beyond a Legal Understanding of International Norms," Cambridge Review of International Affairs 24, no. 2 (2011): 245-264.

38. UN Security Council, Res. S/RES/2098.

39. Similar discussions were had about the interventions in Somalia and Bosnia and Herzegovina in the early 1990s. See Ramesh Thakur, "From Peacekeeping to Peace Enforcement: The UN Operation in Somalia," Journal of Modern African Studies 32, no. 3 (1994): 387-410; Shashi Tharoor, "Should UN Peacekeeping Go 'Back to Basics'?" Survival: Global Politics and Strategy 37, no. 4 (1995): 52-64.

40. UN News, “'Intervention Brigade' Authorized as Security Council Grants Mandate Renewal for United Nations Mission in Democratic Republic of Congo."

41. Ibid.

42. "Resolution Establishing a UN Mission in Mali," What's in Blue: Insights on the Work of the UN Security Council, 24 April 2013, www.whatsinblue.org.

43. United Nations, "UN Peacekeeping: The 'New Horizon' Process," www.un.org /en/peacekeeping/operations/newhorizon.shtml.

44. United Nations, "Report of the Secretary General, Implementation of the Recommendations of the Special Committee on Peacekeeping Operations," UN Doc. A/64/573 (22 December 2009).

45. UN Department of Peacekeeping Operations and Department of Field Support, A New Partnership Agenda: Charting a New Horizon for UN Peacekeeping, July (New York: UN, 2009).

46. Ibid.

47. UN Security Council Meeting Record S/PV.7196 (11 June 2014). 
48. Aljazeera, "M23 Says It Will 'Fight Back’ Against UN,” 6 April 2013.

49. Alex J. Bellamy, "Are New Robust Mandates Putting UN Peacekeepers More at Risk?" Global Observatory (2014), http://theglobalobservatory.org.

50. A UN integrated mission is defined as "one in which there is a shared vision among all UN actors as to the strategic objective of the UN presence at country level." United Nations, "Integrated Missions Planning Process (IMPP), Guidelines Endorsed by the Secretary-General on 13 June 2006," https://docs.unocha.org.

51. International Forum for the Challenges of Peace Operations, Consideration for Mission Leadership in United Nations Peacekeeping Operations (Stockholm: Edita Vastra Aros AB, 2010).

52. Mark Duffield, "Risk-management and the Fortified Aid Compound: Everyday Life in Post-interventionary Society," Journal of Intervention and Statebuilding 4, no. 4 (2010): 453-474; Lisa Smirl, "Building the Other, Constructing Ourselves: Spatial Dimensions of International Humanitarian Response," International Political Sociology 2, no. 3 (2008): 236-253.

53. Victoria Metcalfe, Alison Giffen, and Samir Elhawary, "UN Integration and Humanitarian Space: An Independent Study Commissioned by the UN Integration Steering Group" (London: Overseas Development Institute and Stimson Center, 2011), p. 1; Oliver Ulrich, "Integration: Recent Developments and Consistent Misperceptions," Humanitarian Exchange Magazine 46 (2010): 39-41.

54. Lise Morje Howard, UN Peacekeeping in Civil Wars (Cambridge: Cambridge University Press, 2008), p. 8.

55. UN News, "UN Envoy Tells Security Council There Is 'Renewed Opportunity' for DR Congo Peace Efforts" (6 May 2013), www.un.org/apps/news/story .asp?NewsID=44836.

56. IRIN News, "Briefing: North Kivu Sees Fresh Clashes as Peace Talks Stall in Kampala," 18 July 2013.

57. Risdel Kasasira, "Kabila Signs Amnesty for M23 Rebels," Daily Monitor, 3 May 2014.

58. Morten Bøås and Mats Utas, "Introduction: Post-Gaddafi Repercussions in the Sahel and West Africa," Strategic Review for Southern Africa 35, no. 2 (2013): $3-15$. 